\title{
Isolation and Identification of Antibacterial Compound from Punica granatum L. Fruit Peels Grown in Iraq
}

\section{Mohammed Taha Mahmood}

Department of Basic Sciences / College of Nursing University of Mosul

Muthanna J. Mohammed

Firas Abbas Al-Bayati

Department of Biology / College of Education

University of Mosul, Iraq

Received
03 / 05 / 2010
Accepted

27 / 06 / 2010

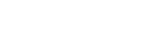

هذفت الدرلسة الحالية إلى فصل وتشخيص المركب المسؤول عن الفعالية الدوائية من

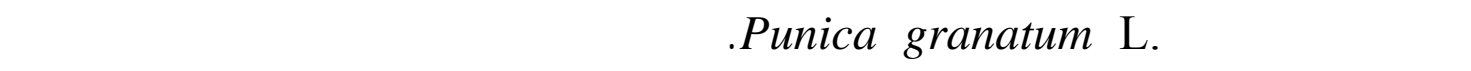

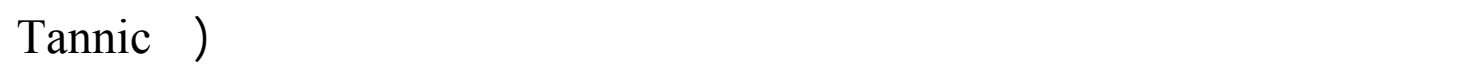

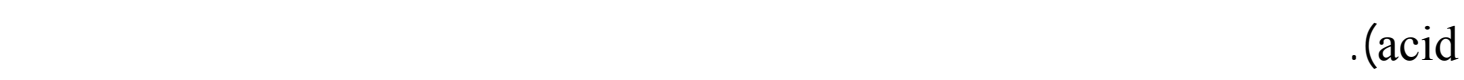

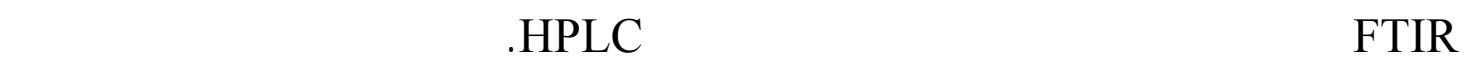

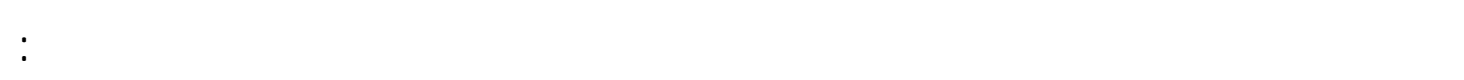

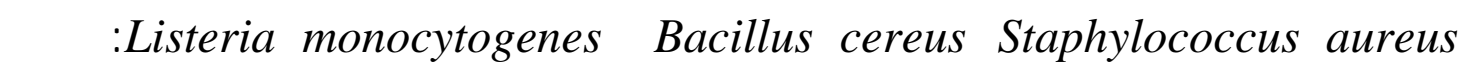
Klebsiella pneumoniae ،Brucella melitensis البكتريا للسالبة لصبغة كرلم فتضمن

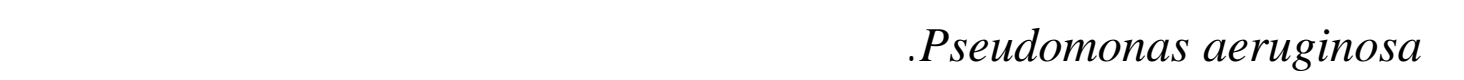

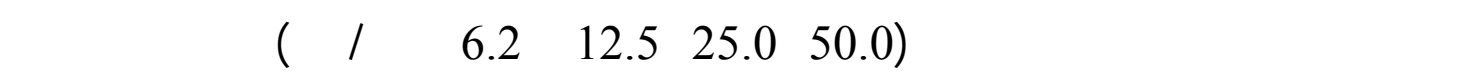

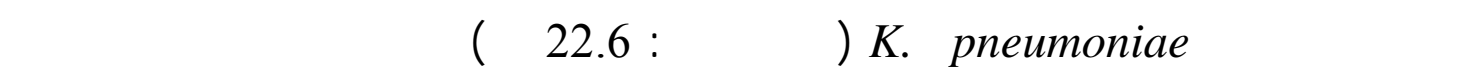

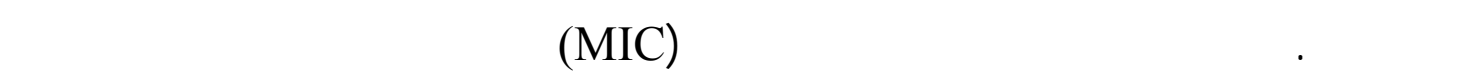

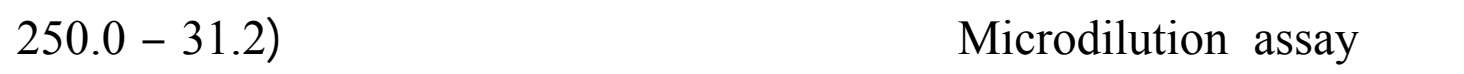

مايكروغرل/dل) وأعلى قيمة تنبيط كلت ضدد بكتريا K. pneumoniae. 


\section{Abstract}

The aim of this study was to isolate and identify the substance responsible for the pharmacological activities of Punica granatum L. fruit peels. Tannic acid (ellagitannins, gallotannins) was isolated from pomegranate fruit husk and detected on Thin layer chromatography TLC plates in comparison with standard tannic acid that, served as a positive control. Moreover, infrared FTIR spectrometer and High Performance Liquid Chromatography HPLC analysis were used to confirm the purity and characterization of tannic acid. The isolated material was investigated for its antibacterial activity against six different pathogenic bacteria. The Gram-positive bacteria were; Staphylococcus aureus, Bacillus cereus, Listeria monocytogenes; and Gram-negative bacteria included; Brucella melitensis, Klebsiella pneumoniae and Pseudomonas aeruginosa. Tannic acid at different concentrations $(50.0,25.0,12.5,6.2 \mathrm{mg} / \mathrm{ml})$ was active against all tested bacteria and the highest inhibitory effect was observed against K. pneumoniae (zone of inhibition: $22.6 \mathrm{~mm}$ ) using the disc diffusion method. The minimal inhibitory concentration MIC for tannic acid was determined using a broth microdilution method in 96 multi-well microtiter plates. MIC values ranged from $31.2-250.0 \mu \mathrm{g} / \mathrm{ml}$, and the most promising result was observed against $K$. pneumoniae.

\section{Introduction}

The interest in the study of medicinal plants as a source of pharmacologically active compounds has increased worldwide. It is recognized that in some developing countries, plants are the main medicinal source to treat infectious diseases. In these countries living conditions are crowded and hygiene is poor; diarrhea and dysentery caused by bacterial enteropathogens are among the main causes of morbidity and mortality [1,2]. Due to the indiscriminate use of antimicrobial drugs the microorganisms have developed resistance to many antibiotics. This has created immense clinical problem in the treatment of infectious diseases [3]. In addition to this problem, antibiotics are sometimes associated with adverse effects on host which include hypersensitivity, depletion of beneficial gut and mucosal microorganisms, immunosuppression and allergic reactions [4]. Therefore there is a need to develop alternative antimicrobial drugs for the treatment of infectious diseases.

Punica granatum L. (pomegranate) member of Punicaseae family, is a fruit-bearing deciduous shrub or small tree growing to 5-8 $\mathrm{m}$ tall. The tree is native to warm regions like Pakistan, Iran, India and Iraq. Several parts of the tree have been used as an astringent, haemostatic, as a remedy for diabetes, as an anthelmintic specifically against tapeworms and for diarrhea and dysentery [5]. In addition to its antibacterial [6], antiviral [7] 
and antioxidant [8] properties. The pomegranate tree, especially the fruit rind, possesses a vast ethnomedical history and represents a phytochemical reservoir of heuristic medicinal value. In Iraq dried $P$. granatum fruit peels are used for wound healing and for the treatment of diarrhea and dysentery [9].

Tannins are reported to possess multiple biological activities including anticancer [10], antioxidant [11], and antimicrobial activities [12]. Based on their chemical structures, tannins are further divided into hydrolyzable and condensed tannins. The main components of hydrolysable tannins are gallotannins, also referred to as tannic acid, and ellagitannins [10].

Although many reports on the antimicrobial activity of pomegranate exist in the literature, none of them relates such activity with its chemical composition. We describe here the isolation, identification and purification of tannic acid (gallotannins) from P. granatum fruit peel and its antibacterial activity against six selected pathogenic bacteria.

\section{Materials and methods}

\section{Chemicals}

Ethyl acetate, petroleum ether, methanol, ethanol, dimethylsulfoxide DMSO, acetone, chloroform, carbon disulfide, benzene, ferric chloride, plumb acetate and potassium dichromate solution were obtained from BDH Analar (England). Tannic acid (standard) $99 \%$ purity (molecular weight $1701.20, \mathrm{mp} 218{ }^{\circ} \mathrm{C}$, molecular formula $\mathrm{C}_{76} \mathrm{H}_{52} \mathrm{O}_{46}$ ) was obtained from Aldrich Chemical Com. (Germany).

\section{Plant material}

P. granatum fruit peels were collected at the end of July 2007 from Mosul countryside, Nineveh Province, Iraq and identified by a botanical taxonomist at college of Agriculture and Forestry, University of Mosul. Peels were washed first under running tap water, followed by sterilized distilled water and dried at room temperature in dark then grinded to powder using an electrical blender.

\section{Isolation and purification of tannic acid}

Tannic acid was extracted from $P$. granatum fruit peels according to the method described by [13]. Briefly, the powdered peels were extracted with water, using a soxhlet extractor for $8 \mathrm{~h}$ or until the solvent turned pure and colorless. The resulted aqueous solution was treated with ethyl acetate for several times. The solvent was then removed using a rotary vacuum evaporator at $40{ }^{\circ} \mathrm{C}$ to give the concentrated extract (semi solid), which was transformed to solid form by adding petroleum ether. 


\section{Characterization of pure tannic acid}

\section{Chemical detection}

Tannic acid was detected according to its ability to dissolve in water, ethanol, acetone, petroleum ether, chloroform, carbon disulfide, benzene, and according to its reaction with ferric chloride, mineral salts like plumb acetate and potassium dichromate solution [14].

\section{Thin layer chromatography TLC}

The isolated compound from $P$. granatum fruit peels was dissolved in appropriate solvent, applied to silica gel plates, Merck (Germany) $20 \times 20 \mathrm{~cm}, 0.25 \mathrm{~mm}$ in thickness, and developed using the solvent system methanol: chloroform $(2: 1) \mathrm{v} / \mathrm{v}$ [15]. The separated zone was visualized spraying with $0.1 \%(\mathrm{w} / \mathrm{v})$ ferric chloride $\mathrm{FeCl}_{3}$. Standard tannic acid served as positive control [16].

\section{FTIR studies}

Infrared (IR) spectra of tannic acid was recorded in the College of Education, Department of Chemistry, University of Mosul, using a computerized Tensor 27 FTIR spectrometer, Bruker Co. (Germany), in the range $400-4000 \mathrm{~cm}^{-1}$ by $\mathrm{KBr}$ pellet technique.

\section{High-performance liquid chromatography (HPLC)}

HPLC analysis was performed in College of Science, University of Mosul, using a Shimadzo LC 2010 HPLC system (Kyoto, Japan), equipped with a Shimadzo LC 2010 UV-VIS detector with a thermostatted flow cell and a selectable two wavelengths of 190-370 nm or $371-600 \mathrm{~nm}$. The detector signal was recorded on a Shimadzo LC 2010 integrator. The column used was a C18 block heating-type Shimpack VP-ODS (4.6 $\mathrm{mm}$ interior diameter $\times 150 \mathrm{~mm}$ long) with a particle size of $5 \mu \mathrm{m}$. Tannic acid was separated with a mobile phase of water: acetone: methanol $(80: 10: 10)$ at a flow-rate of $3.0 \mathrm{ml} / \mathrm{min}$, column temperature $25^{\circ} \mathrm{C}$. Injection volume was $40 \mu \mathrm{l}$ and detection was carried out at $220 \mathrm{~nm}$ [17].

\section{Bacterial strains}

All microorganisms were obtained from Department of Basic Sciences, College of Nursing, University of Mosul, Iraq. Three strains of Gram-negative bacteria (Brucella melitensis, Klebsiella pneumoniae, Pseudomonas aeruginosa) and three strains of Gram-positive bacteria (Staphylococcus aureus, Bacillus cereus, Listeria monocytogenes) were used as tested bacteria. The cultures of bacteria were maintained in their appropriate agar slants at $4{ }^{\circ} \mathrm{C}$ throughout the study and used as stock cultures. 


\section{Antibacterial activity}

\section{Disc diffusion assay}

A modified agar diffusion method [18] was used to determine antibacterial activity with slight modifications. Nutrient agar was inoculated with microbial cell suspension $(200 \mu \mathrm{l}$ of bacterial cell suspension in $20 \mathrm{ml}$ medium) and poured into sterile Petri dishes. Sterile filter paper discs $6 \mathrm{~mm}$ in diameter were impregnated with $20 \mu \mathrm{l}$ of tannic acid in different concentrations $(50.0,25.0,12.5,6.2 \mathrm{mg} / \mathrm{ml}$ initially prepared by dissolving in DMSO and sterilized by filtration through 0.45 $\mu \mathrm{m}$ millipore filters), and placed on the inoculated agar surface. Standard $6 \mathrm{~mm}$ discs containing gentamycin $10 \mu \mathrm{g} /$ disc and chloramphenicol 30 $\mu \mathrm{g} /$ disc (Bioanalyse) were used as positive controls. The plates were incubated overnight at $37^{\circ} \mathrm{C}$ and the diameter of any resulting zones of growth inhibition was measured $(\mathrm{mm})$. Each experiment was tested in triplicate.

\section{Microdilution assay}

Minimal inhibitory concentrations MIC were determined based on a microdilution method in 96 multi-well microtiter plates as previously described [19]. Briefly, bacterial strains were cultured overnight at $37^{\circ} \mathrm{C}$ on Nutrient broth and adjusted to a final density of $10^{6} \mathrm{cfu} / \mathrm{ml}$, and used as an inoculum. Tannic acid was dissolved in DMSO and then in Nutrient broth to reach a final concentration of $500.0 \mu \mathrm{g} / \mathrm{ml}$. Serial twofold dilutions were made in a concentration range from 7.8 to $500.0 \mu \mathrm{g} / \mathrm{ml}$. In each microtiter plate, two columns with broad-spectrum antibiotics were used as positive controls (gentamycin and chloramphenicol in serial dilutions 7.8-500.0 $\mu \mathrm{g} / \mathrm{ml}$ ). As an indicator of bacterial growth, $40 \mu 1 p$ iodonitrotetrazolium violet (INT) dissolved in water was added to the wells and incubated at $37^{\circ} \mathrm{C}$ for $30 \mathrm{~min}$ [20]. The lowest concentration of tannic acid showing no growth was taken as its minimal inhibitory concentration. The colorless tetrazolium salt acts as an electron acceptor and is reduced to a red-colored formazan product by biologically active organisms [21]. Where bacterial growth was inhibited, the solution in the well remained clear after incubation with INT.

\section{Results}

In the present study tannic acid was isolated from $P$. granatum fruit peels, and then detected on TLC plates in comparison with standard tannic acid. Both, isolated and standard compounds had the same retention factor $\left(R_{f}\right)$ values 0.94 . The FTIR spectrum confirmed the isolated material from P. granatum fruit peels as Tannic acid (Figure 1). Infrared spectrum showed significant peaks which, confirms the purity of the isolated material and were around: $(3382.24) \mathrm{cm}^{-1}$ (s) that corresponds to phenolic hydroxyl; (1714.81) $\mathrm{cm}^{-1}$ (s) which is attributed to carbonyl bond of free and bonded carboxylic groups; (1230) $\mathrm{cm}^{-1}$ corresponds to 
phenolic $(\mathrm{C}-\mathrm{O})$ bond; $(1416-1614) \mathrm{cm}^{-1}$ bands correspond to aromatic rings on tannins structure; $(2935.43) \mathrm{cm}^{-1}$ which ascribes to $(\mathrm{C}-\mathrm{H})$ bond. Moreover, tannic acid was characterized using HPLC method (Figure 2) and identified by comparing its retention time $\left(t_{R}\right)$ and UV spectra with that of the standard compound. The retention time (4-6 min) and UV spectra of the isolated material on HPLC was completely identical to that of standard tannic acid (Figure 3).

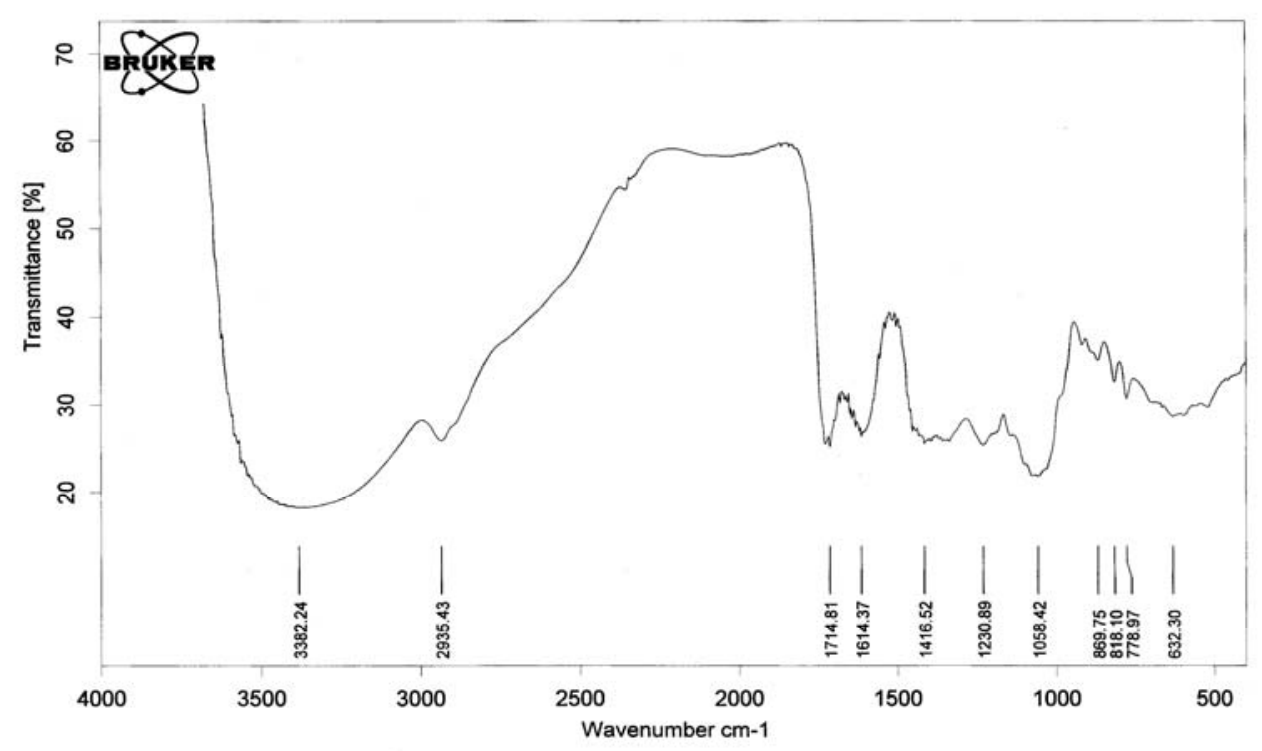

Figure 1. FTIR spectra of tannic acid isolated from $P$. granatum fruit peels.

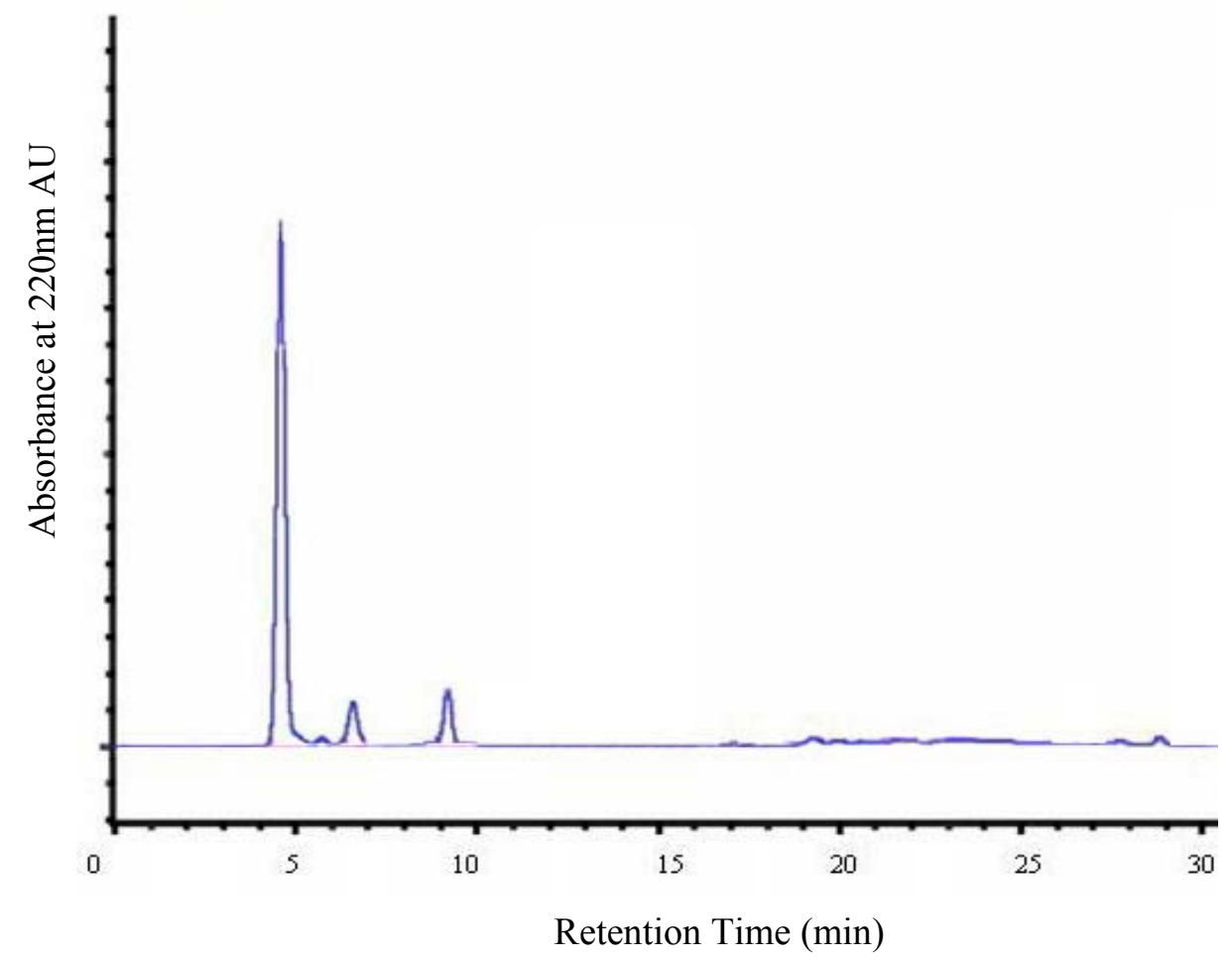

Figure 2. HPLC chromatogram of tannic acid isolated from $P$. granatum fruit peels. 


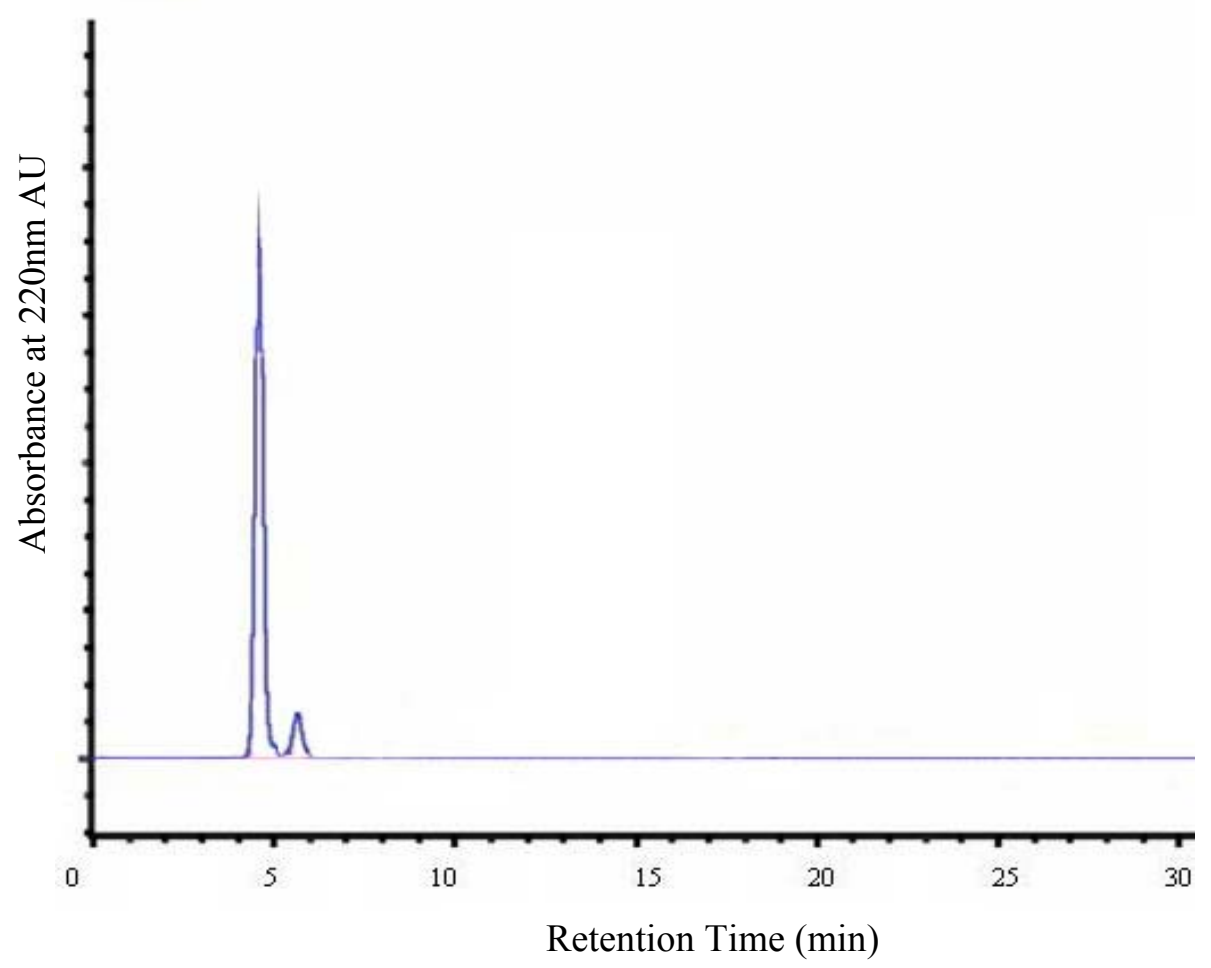

Figure 3. HPLC chromatogram of standard tannic acid.

The isolated material was then investigated for its antibacterial activity against six bacterial species. The initial screening of antibacterial activity of tannic acid was assayed in vitro by the agar diffusion method using four concentrations (50.0, 25.0, 12.5, $6.2 \mathrm{mg} / \mathrm{ml})$. All concentrations were active against all tested bacteria (Table 1) and the highest inhibitory effect was observed against K. pneumonia (zone of inhibition: $22.6 \mathrm{~mm}$ ) using the concentration $50.0 \mathrm{mg} / \mathrm{ml}$, while the weakest activity was demonstrated against $P$. aeruginosa (zone of inhibition: $10.0 \mathrm{~mm}$ ) using the concentration $6.2 \mathrm{mg} / \mathrm{ml}$.

Table 1. Antibacterial activity of tannic acid isolated from $P$. granatum fruit peels

\begin{tabular}{lcccccc}
\hline & \multicolumn{5}{c}{ Zone of inhibition (mm) } \\
\cline { 2 - 7 } Microorganisms & \multicolumn{5}{c}{ Tannic acid concentrations } & Control $(\mu \mathrm{g} / \mathrm{disc})$ \\
\cline { 2 - 7 } & 50.0 & 25.0 & 12.5 & 6.2 & $\mathrm{G}$ & $\mathrm{C}$ \\
\hline S. aureus & 20.1 & 18.6 & 15.4 & 12.2 & 16.1 & 24.4 \\
B. cereus & 18.3 & 16.9 & 13.5 & 10.4 & 18.3 & 21.2 \\
L. monocytogenes & 19.2 & 16.2 & 14.3 & 10.7 & 20.3 & - \\
B. melitensis & 21.3 & 18.3 & 14.3 & 11.8 & 16.3 & - \\
K. pneumonia & 22.6 & 19.3 & 15.4 & 12.5 & 14.2 & 20.2 \\
$P$. aeruginosa & 17.2 & 15.5 & 13.2 & 10.0 & 16.0 & 23.1 \\
\hline
\end{tabular}

G: Gentamycin $10 \mu \mathrm{g} /$ disc; C: Chloramphenicol $30 \mu \mathrm{g} / \mathrm{disc}$; -: No activity. 
In view of the results obtained by the disc diffusion method, the minimal inhibitory concentration MIC for tannic acid isolated from $P$. granatum fruit peels was determined by broth microdilution assay (Table 2). K. pneumonia was found to be the most sensitive pathogen against tannic acid with a MIC value of $31.2 \mu \mathrm{g} / \mathrm{ml}$ while, $S$. aureus, $B$. melitensis ranked next (MIC $62.5 \mu \mathrm{g} / \mathrm{ml}$ ) followed by B. cereus, $L$. monocytogenes (MIC $125.0 \mu \mathrm{g} / \mathrm{ml}$ ) and finally, P. aeruginosa with a MIC value of $250.0 \mu \mathrm{g} / \mathrm{ml}$. The standard drugs gentamycin and chloramphenicol were active against most reference bacteria (zone of inhibition range: $14.2-20.3$ and $20.2-24.4 \mathrm{~mm}$ respectively; MIC range: $7.8-31.2$ and $7.8 \mu \mathrm{g} / \mathrm{ml}$ respectively).

Table 2. Minimum inhibitory concentration MIC of tannic acid isolated from $P$. granatum fruit peels.

\begin{tabular}{lccc}
\hline & \multicolumn{3}{c}{ MIC values $(\mu \mathrm{g} / \mathrm{ml})$} \\
\cline { 2 - 4 } Microorganisms & Tannic acid & Control \\
\cline { 2 - 4 } & 62.5 & 15.6 & $\mathrm{C}$ \\
\hline S. aureus & 125.0 & 15.6 & 7.8 \\
B. cereus & 125.0 & 7.8 & - \\
L. monocytogenes & 62.5 & 15.6 & - \\
B. melitensis & 31.2 & 31.2 & 7.8 \\
K. pneumonia & 250.0 & 15.6 & 7.8 \\
P. aeruginosa & &
\end{tabular}

G: Gentamycin; C: Chloramphenicol; -: No activity.

\section{Discussion}

Tannins are high molecular weight plant polyphenolic compounds found in foods such as legumes, vegetables, fruits, and beverages [10]. Pomegranate fruit husk/peel is a rich source of hydrolyzable tannins $(26 \%)$ called ellagitannins or tannic acid, and is employed both as a medicine and for tanning [22].

Almost, all parts of $P$. granatum have been reported to have antibacterial activity such as roots [23], fruits [24] and fruit rind [25, 6, 26]. All these studies focused on extracts from pomegranate tree parts and none of them related such activity with the plant chemical composition. In vitro studies in this work showed that tannic acid, the major constituent of tannins and a mixture of several structurally related gallotannin compounds, was active against all tested bacteria. The zones of inhibition ranged from 10.0-22.6 $\mathrm{mm}$ in diameter using the disc diffusion method. Furthermore, MIC values ranged from 31.2-250.0 $\mu \mathrm{g} / \mathrm{ml}$, and the most promising result was observed against $K$. pneumonia.

Tannins are known to complex irreversibly with nucleophilic amino acids in proteins, often leading to inactivation of the protein and 
loss of function. For this reason, the potential range of tannins antimicrobial effects is great. Probable targets in the microbial cell are surface-exposed adhesins, cell wall polypeptides, and membrane-bound enzymes. Tannins may also render substrates unavailable to the microorganism [12].

In the present study the standard drug gentamycin was active against all tested bacteria in contrast to chloramphenicol which, had no activity against $L$. monocytogenes and $B$. melitensis. On the other hand chloramphenicol showed better results against all sensitive pathogens than that of gentamycin. Several mechanisms of antimicrobial resistance are readily spread to a variety of bacterial genera. First, the organism may acquire genes encoding enzymes, such as $\beta$-lactamases, that destroy the antibacterial agent before it can have an effect. In addition, bacteria may acquire efflux pumps that extrude the antibacterial agent from the cell before it can reach its target site and exert its effect. Finally, bacteria may acquire several genes for a metabolic pathway which ultimately produces altered bacterial cell walls that no longer contain the binding site of the antimicrobial agent, or bacteria may acquire mutations that limit access of antimicrobial agents to the intracellular target site via downregulation of porin genes [27].

It can be concluded that tannic acid isolated from $P$. granatum fruit peels had strong antibacterial activities against six different bacterial species and that tannic acid is very much responsible for the antibacterial activity of Pomegranate fruit rind. Additional in vivo studies and clinical trials would be needed to justify and further evaluate the potential of this compound as an antibacterial agent in topical or oral applications.

\section{References}

1) World Health Organization, Bulletin of WHO, 71: 335-336 (1996).

2) World Health Organization, The World Health Report. WHO, Geneva, Switzerland, 39-60 (1998).

3) Davis, J., Science, 264: 375-382 (1994).

4) Idose, O., Guthe, T., Willeox, R., Deweck, A.L., Bulletin of WHO, 38: 159-188 (1968).

5) Das, A.K., Mandal, S.C., Banerjee, S.K., Sinha, S., Das, J., Saha, B.P., Pal, M., J. Ethnopharmacol., 68: 205-208 (1999).

6) Prashanth, D., Asha, M.K., Amit, A., Fitoterapia, 72: 171-173 (2001).

7) Parmar, C., Kaushal, M.K., Wild Fruits of the Sub-Himalayan Region. New Delhi: Kalyani Publishers (1982).

8) Mertens-Talcott, S.U., Jilma-Stohlawetz, P., Rios, J., Hingorani, L., Derendorf, H., J. Agric. Food Chem., 15: 8956-8961 (2006). 
9) Majeed, S.H., Mahmood, M.J., Herbs and Medicinal Plants in Iraq Between Traditional Medicine and Scientific Research $\left(1^{\mathrm{st}} \mathrm{Ed}\right)$. Baghdad: Dar Al-Thaowra for Publishing (1988).

10) Okuda, T., Yoshida, T., Hatano, T., Fortschritte der Chemie Organischer Naturstoffe, 66: 111-117 (1995).

11) Hagerman, A.E., Riedl, K.M., Jones, J.A., Sovik, K.N., Ritchard, N.T., Hartzfeld, P.W., Riechel, T.L., J. Agric. Food Chem., 46: 1887-1892 (1998).

12) Cowan, M.M., Clin. Microbiol. Rev., 12: 564-582 (1999).

13) Panshin, A.J., Harrar, E.S., Bethel, J.S., Baker, W.J., Forest Products-Their Sources, Production and Utilization. New York: McGraw-Hill (1962).

14) Shriner, R.L., Fuson, R.C., Curtin, D.Y., The Systematic Identification of Organic Compounds $\left(5^{\text {th }}\right.$ Ed). New York: John Wiley \& sons, Inc (1964).

15) Pansera, M.R., Iob, G.A., Atti-Santos, A.C., Rossato, M., AttiSerafini, C.E., Braz. Arch. Biol. Technol., 47: 995-998 (2004).

16) Sharma, O.P., Bhat, T.K., Singh, B., J. Chromatography A, 822: 167-171 (1998).

17) Seeram, N., Lee, R., Hardy, M., Heber, D., Separation and Purification Technology, 41: 49-55 (2005).

18) Mothana, R.A., Lindequist, U., J. Ethnopharmacol., 96: 177-181 (2005).

19) Swanson, K.M., Busta, F.F., Peterson, E.H., Johanson, M.G., Colony count methods. In: Vanderzant, C., Splittstoesser, D.F., (Ed). Compendium of Methods for Microbiological Examination of Food $\left(3^{\text {rd }}\right.$ Ed). Washington: American Public Health Association (1992).

20) Buwa, L.V., van Staden, J., J. Ethnopharmacol., 103: 139-142 (2006).

21) Eloff, J.N., Planta Medica, 64: 711-713 (1998).

22) Muthaliar, M., Siddha Materia Medica $\left(4^{\text {th }}\right.$ Ed) India, Chennai: Tamilnadu Siddha Medical Council (1988).

23) Mathabe, M.C., Nikolova, R.V., Lall, N., Nyazema, N.Z., J. Ethnopharmacol., 105: 286-293 (2006).

24) Melendez, P.A., Capriles, V.A., Phytomedicine, 13: 272-276 (2006).

25) Alanıs, A.D., Calzada, F., Cervantes, J.A., Torres, J., Ceballos, G.M., J. Ethnopharmacol., 100: 153-157 (2005).

26) Perez, C., Anesini, C., J. Ethnopharmacol., 44: 41-46 (1994).

27) Tenover, F., Amer. J. Med., 119: S3-S10 (2006). 